International Research Journal of Management, IT \& Social Sciences
Available online at https://sloap.org/journals/index.php/irjmis/
Vol. 6 No. 6, November 2019, pages: 244 252
ISSN: 2395-7492
https://doi.org/10.21744/irjmis.v6n6.807

\title{
Talent Acquisition and Talent Engagement Practices Significant Impact Over Employee Satisfaction
}

\author{
Jackqueen Keith Marrybeth ${ }^{\text {a }}$ \\ John Stave Brackz ${ }^{\text {b }}$ \\ William Boy Hadson ${ }^{c}$ \\ Marcus Sandy Zlong ${ }^{\mathrm{d}}$
}

Article history:

Received: 09 July 2019

Accepted: 30 September 2019

Published: 21 November 2019

\section{Keywords:}

acquisition;

business;

development;

engagement;

retention;

\begin{abstract}
It is observed that talent acquisition and talent engagement practices have a significant impact on employee satisfaction in the deemed universities. It is also disclosed that talent development and talent retention practices are found to be insignificant. It clearly indicates that the deemed universities are keen on talent acquisition and talent engagement, but they are failed in implementing talent development as well as talent retention strategies. Further, this analysis unveiled that talent acquisition and talent development practices have a significant impact on employee satisfaction in business schools. It is also disclosed that the talent engagement and talent retention practices are found to be insignificant. It clearly indicates that business schools are keen on talent acquisition and talent development, but they are failed in implementing talent engagement as well as talent retention strategies.
\end{abstract}

2395-7492@ Copyright 2019. The Author. This is an open-access article under the CC BY-SA license (https://creativecommons.org/licenses/by-sa/4.0/) All rights reserved.

\section{Author correspondence:}

Jackqueen Keith Marrybeth,

The Australian National University, Canberra, Australia.

Email address: marrybeth@federation.edu.au

\section{Introduction}

Tarique \& Schuler (2010); Snipes et al., (2005), Economic mobility of high-skilled is the key to understand the 21st Century World of Brain Circulation. Brain Circulation refers to the individuals with high skills or high potential migrates from one Country to another Country to study or to seize employment and entrepreneurship opportunities, traditionally referred to as Brain Drain for one country and Brain Gain for the other. There is a paradigm shift from 'Brain Drain' to 'Brain Circulation' through 'Brain Gain' of the 21 st Century. This can be viewed by replacing lowskilled workers by robots while knowledge workers are displaced by algorithms. In the present era of frugal innovation, mobility develops talent. The global mindset, the networks, the innovative capabilities characterize creative talent,

a The Australian National University, Canberra, Australia

b The Australian National University, Canberra, Australia

${ }^{c}$ Monash University, Melbourne, Australia

${ }^{\mathrm{d}}$ Monash University, Melbourne, Australia 
international mobility and brain circulation. The corporate is competing globally to grow better talents, attract the talents they need, and to retain those that bring them competitiveness, innovation, and growth in all spheres of economic, social, political and technological fronts. Hiring, managing, and retaining highly skilled talents include identifying 'Talent Pools' and effectively staffing leadership positions (Beechler \& Woodward (2009). It is the moot point of all organizations around the world to attract, develop, and retain a needed supply of critical talent. Finding, taking and retaining the right talent at the right place, at the right time, and at the right price is an important global issue for every enterprise (Hartmann et al., 2010; Cooke et al., 2014).

\section{Review of Literature on HRD Practices in Talent Management}

According to Schiemann (2014), in simple terms, HRD Practices is the identification and development of potential and it attracts, develops, nurtures and retains people with the skill and abilities to drive current and future growth (Meyers \& Van Woerkom, 2014). The components of TM comprise (i) Identification of Talent; (ii) Development of Talent; and (iii) Engagement of Talent (Budhwar \& Sparrow, 2002).

The first and foremost component i.e., Talent Identification is the process of identifying key positions and roles that are required to support the design and deployment of strategic and operational plans and initiatives. The second component i.e., Talent Development deals with the internal as well as external talent development. Internal talent development integrates the processes of training, performance management, coaching, special projects, career development, etc., while external talent development is essential for recruitment and selection.

The third component, 'Talent EMR' is an acronym for Engagement, Motivation, and Retention which refers to build, align and support the strategic talent pool of the organization. Managing talent is the systematic attraction, identification, development, engagement, retention, and deployment of individuals with high potentials who are of particular value to an organization (Dries, 2013). HRD Practices is a set of processes aimed at the creation of databases of talents (Talent Pools) (Gelens et al., 2013) for the (i) identification and absorption of talent; (ii) maintenance of talent and (iii) development of talent (Thunnissen et al., 2013). It is an Integrated HRM strategy aimed at improving the efficiency of an organization through the process of Recruitment, Selection, Development, and Performance Appraisal (de Araújo Burcharth et al., (2014). The HRD Practices life cycle can take place in several successive steps starting from (i) Workforce Planning (ii) Talent Acquisition (iii) Talent Engagement (iv) Talent Development (v) Deploy Talent (vi) Lead Talent and (vii) Retaining Talent (Cardon \& Stevens (2004). From a broad perspective, HRD Practices is defined as the strategic management of the flow of talent through an organization and could help an organization to align the right people with the right jobs at the right time based on business priorities (Hiltrop, 1996). Talent Acquisition: The acquiring, accessing and assimilating 'Talent' is vital for organizations in attaining effectiveness and performance. In order to compete in the hypercompetitive environment, people with diverse backgrounds and talents are immense need to anticipate competitors' moves. However, to attract the best people and to analyze the competencies, credentials it is required to evaluate the Employee Value Proposition (EVP) (Epstein, 2005).

\section{Talent Engagement}

Talent Engagement refers to an individual's purpose and focused energy, evident to others in the display of personal initiative, adaptability, effort, and persistence directed towards organizational goals (Hall \& Moss, 1998). It is a positive fulfilling work related to the state of mind that is characterized by vigor, dedication, and absorption (Vaiman et al., (2015). Talent Engagement is defined as the extent to which individuals are committed to their organization and its bottom-line, have pride and job ownership, and put for the more discretionary effort in terms of time and energy. It is one of the key drivers for ensuring enhanced, effective productivity and efficient performance and a critical and pivotal factor for the success of either an individual or an organization. The Engaged Talent bounds intellectually and emotionally with the organization, feel passionate about goals and committed to values. It represents an alignment of maximum job satisfaction with minimum job contribution.

\section{Talent Development}

Talent Development is a prima facie for organizations to compete in new markets with minimal resources. The survival and longevity of organizations depend on the products, innovative processes, and organizational management (Yang, 2007). The Talent Development pipeline architecture consists of a clear statement of talent development needs and

Marrybeth, J. K., Brackz, J. S., Hadson, W. B., \& Zlong, M. S. (2019). Talent acquisition and talent engagement practices significant impact over employee satisfaction. International Research Journal of Management, IT and Social Sciences, 6(6), 244-252. https://doi.org/10.21744/irjmis.v6n6.807 
developmental pathways and a blend of developmental strategies (Gallardo-Gallardo et al., 2015). The Talent pipeline architecture deals with the issues of stakeholder engagement, communication activities, and decisions concerning the target groups for talent development activities and the extent of standardization of talent development processes and systems across the organizations.

\section{Talent Retention}

The irreversible shift from the Industry-2.0 to Industry-4.0, the intensifying demand for HR analytics and the growing propensity of start-ups being a defining feature of the HRD Practices especially Talent Retention'. Globally, the waves of 'Turnover of Talents' are taking a toll in the form of Fire, Cuts, Lay-offs, Outsourcing, and Downsizing and that paves the way for 'Attraction and Retention of Talents'. Retaining Talent has become a strategic need for many organizations around the world to maintain a competitive workforce (De Long et al., 2003). The prime issue of HR leaders in the struggle for 'Retaining Talents' in order to meet business objectives. The efforts made by an employer to keep skilled workers are defined as 'Talent Retention'. Talents are unique and scarce, hence retaining talent requires long-term thinking and creative planning (Bedarkar \& Pandita, 2014).

\section{Research Gap}

There is adequate literature on HRD Practices and their impact on the different variables in the various sectors. Very few research evidence is available in the context of the Hotel sector. Even in the available literature also, the role of HRD Practices such as talent acquisition, talent development, talent engagement and talent retention on employee satisfaction is not clear and the studies of the results on these variables were contradicting with each other. Furthermore, the research was carried on individual factors and no efforts were found to check their collective impact on employee satisfaction. The mediating role of organizational culture is also tested on various aspects of past research, but no attempt was done to check on HRD Practices over employee satisfaction. In this context, it is required to understand the mediating role organization culture and value over HRD Practices such as talent acquisition, talent development, talent engagement and talent retention on employee satisfaction. Hence this study identified as a research gap to test the mediating role of organizational culture and values over HRD Practices over employee satisfaction in the Hotel sector.

With these conclusions, this study derived a conceptualized model to assess the mediating impact of organization culture on HRD Practices on employee satisfaction in the Hotel sector. The model has been presented in the following figure 1.

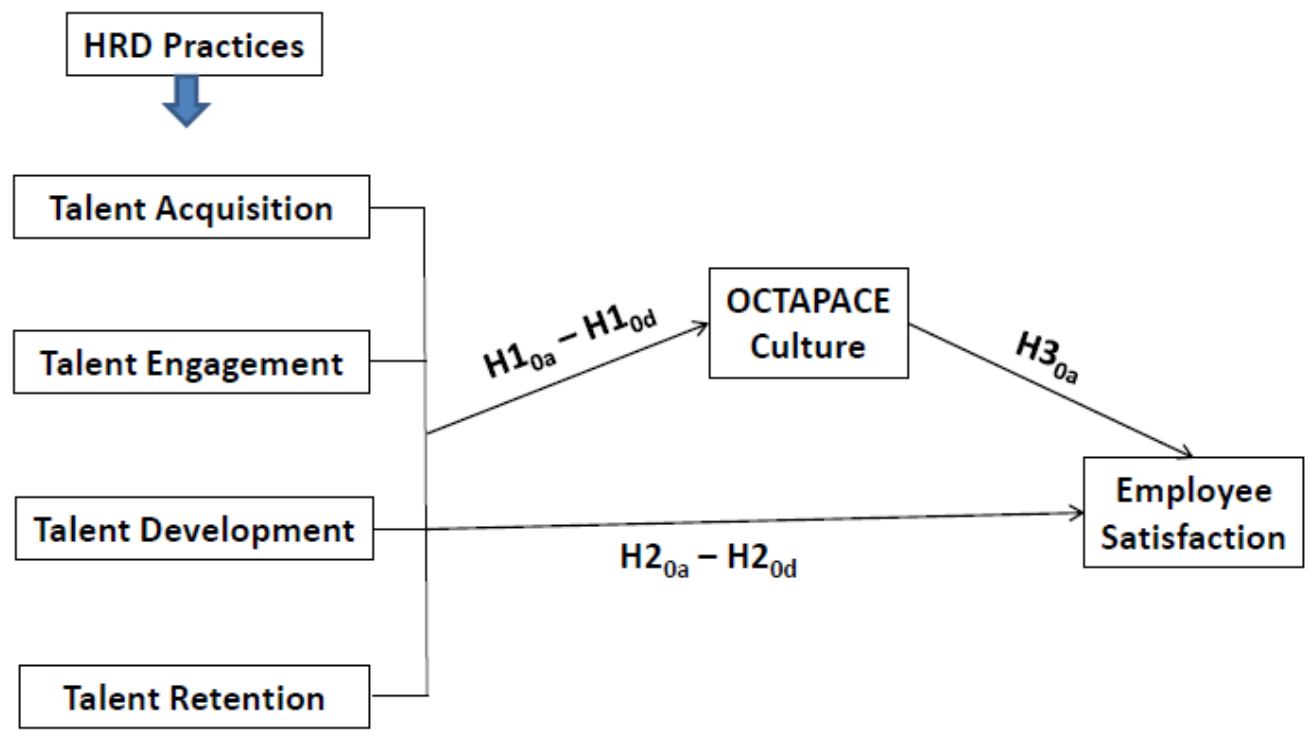

Figure 1. Hypothesized conceptual framework 
Research Questions

The current study derived the following research questions based on the exploratory research which was carried out by the researcher. The research questions are as follows:

1) Does the OCTAPACE Culture mediate the impact of talent acquisition on employee satisfaction?

2) Does the OCTAPACE Culture mediate the influence of talent engagement on employee satisfaction?

3) Does the OCTAPACE Culture mediate the effect of talent development on employee satisfaction?

4) Does the OCTAPACE Culture mediate the effect of talent retention on employee satisfaction?

\section{Research Objectives:}

To explore the factors influencing HRD Practices such as talent acquisition, talent engagement, talent development, and talent retention and the factors affecting employee satisfaction.

1) To examine the impact of talent acquisition on employee satisfaction through the mediating role of OCTAPACE Culture.

2) To analyze the effect of talent engagement on employee satisfaction through the mediating role of OCTAPACE Culture.

3) To analyze the effect of talent development on employee satisfaction through the mediating role of OCTAPACE Culture.

4) To analyze the effect of talent retention on employee satisfaction through the mediating role of OCTAPACE Culture.

\section{Hypotheses Formulation}

As the present study's model has been derived from the exploratory study, the null hypothesis is formulated. The proposed hypotheses accordingly are as follows:

Hypothesis 1:

$\mathrm{H} 1_{0}$ : OCTAPACE Culture will not have a mediating effect on employee satisfaction in relation to

$\mathrm{H}_{10 \mathrm{a}}$ : Talent Acquisition; $\mathrm{H}_{10 \mathrm{~b}}$ : Talent Engagement; $\mathrm{H}_{0 \mathrm{c}}$ : Talent Development;

$\mathrm{H} 1_{0 \mathrm{~d}}$ : Talent Retention

Hypothesis 2:

$\mathrm{H} 2_{0}$ : HRD Practices will not have an effect on employee satisfaction in relation to

$\mathrm{H} 2_{0 \mathrm{a}}$ : Talent Acquisition; $\mathrm{H}_{20 \mathrm{~b}}$ : Talent Engagement; $\mathrm{H} 2_{0 \mathrm{c}}$ : Talent Development;

$\mathrm{H} 2_{0 \mathrm{~d}}$ : Talent Retention

Hypothesis 3:

$\mathrm{H} 3_{0}$ : OCTAPACE Culture will not have a significant effect on employee satisfaction.

\section{Research Design}

The past research information which is available on HRD Practices, OCTAPACE Culture and employee satisfaction is very limited, especially the information in the Indian context is very fragmentary. In this scenario, we adopted both the qualitative and quantitative research approaches to explore and examine the determinant factors of HRD Practices towards OCTAPACE Culture which in turn affects employee satisfaction in higher education. The personal interviews and extensive discussions with academicians, researchers and the senior employees helped to recognize and classify the factors such as institutional brand, recruitment, and selection, infrastructure, work environment and compensation which influence talent acquisition. The variables namely role clarity, goal clarity and work-life balance influencing talent engagement. The variables such as learning and professional development and performance appraisal prompting talent development. Some other variables such as employee wellness and safety, career management, rewards, and benefits had an impact on talent retention practices in Indian management education. By and large, the relevant literature with respect to the above-mentioned variables and the research findings helped to frame the theoretical framework.

Marrybeth, J. K., Brackz, J. S., Hadson, W. B., \& Zlong, M. S. (2019). Talent acquisition and talent engagement practices significant impact over employee satisfaction. International Research Journal of Management, IT and Social Sciences, 6(6), 244-252. https://doi.org/10.21744/irjmis.v6n6.807 


\section{Materials and Methods}

A combination of descriptive and inferential statistical technique is used to analyze the data gathered on respondent's demographic characteristics, determinant attributes of HRD Practices, mediating factor of OCTAPACE Culture, and the dependent variable employee satisfaction. Using the final dataset, factor analysis is used to condense a large amount of data collected. For identifying the determinant attributes of HRD Practices, principal component analysis, and VARIMAX rotation is performed to determine the factors to be used in the final analysis. Descriptive statistical techniques like mean and standard deviation are applied to both respondents' characteristics, variables associated with HRD Practices. For testing $\mathrm{H}_{0}, \mathrm{H}_{2}$ and $\mathrm{H}_{3}$ inferential statistical techniques like PROCESS mediation analysis are used.

\section{Results and Discussions}

The descriptive analysis, mediation analysis, and inferential statistics were applied to the collected data through the structured questionnaire. The respondent's demographics were analyzed through the cross-tabulation, the impact of concerned independent, mediating and dependent variables were analyzed through the mediating analysis and inferential statistics are used for testing the proposed conceptualized model mentioned in the study.

Demographic Profile of the Respondents:

The primary data was collected from different categories of employees such as operational level employees, tactical level employees, and strategic level employees. Totally data was collected from 315 respondents and analyzed. The demographic and socio-economic characteristics of the respondents are given below.

\section{Socio-economic, Demographic and Geographic characteristics of respondents}

The primary data depicted that, there are 221 male (70.2 percent) and 94 female ( 29.8 percent) respondents. There are 96 (30.5 percent) respondents in the age group of 25-35 years, 135 (42.9 percent) members in the age group of $35-45$ years, 61 (19.4 percent) respondents in the age group of 45-55 years and 23 ( 7.3 percent) respondents with the age 55 and above. Among the total employees, 18 (5.7 percent) are from the Five Star Hotels, 162 (51.4 percent) are from Three Star Hotels and 135 (42.9 percent). The data has been collected from 210 (66.7 percent) operational level cadre, 70 (22.2 percent) tactical level cadre and 35 (11.1 percent) from the strategic level cadre. There are 189 (60 percent) of the employees with Hotel Management, 110 (34.9 percent) employees with Degree as their highest qualification and 16 (5.1 percent) of the employees with other qualifications. The major chunk of the respondents, 127 (40.3 percent) are in the salary range of Rs 20,000 to 30,000 per month, 105 (33.3 percent) are in the salary range of Rs 30,000 to 40,000 per month, 60 (19 percent) are in the salary range of Rs 40,000 to 50,000 per month and 23 ( 7.3 percent) is with more than Rs 50,000 per month. The majority of the respondents 129 (41 percent) have 2 to 5 years of experience, 120 (38.1 percent) have 0 to 2 years of experience. 31 (9.8 percent) have 5 to 10 years of experience and 35 (11.1 percent) of the employees have more than 10 years of experience. The employees member demographic details are summarized in Table 1.

Table 1

Demographic profile of the respondents

\begin{tabular}{llll}
\hline \multicolumn{2}{c}{ Demographic Description } & Frequency & Percentage \\
\hline Gender & Male & 221 & 70.2 \\
Age & Female & 94 & 29.8 \\
& $25-35$ Yrs & 96 & 30.5 \\
& $35-45$ Yrs & 135 & 42.9 \\
\multirow{5}{*}{ Type of Organization } & $45-55$ Yrs & 61 & 19.4 \\
& above 55 yrs & 23 & 7.3 \\
& Five Star Hotel & 18 & 5.7 \\
Cadre of Job & Three Star Hotel & 162 & 51.4 \\
& Two Star Hotel & 135 & 42.9 \\
\hline
\end{tabular}




\begin{tabular}{llll}
\hline \multirow{4}{*}{ Education } & Tactical Level & 70 & 22.2 \\
& Strategic Level & 35 & 11.1 \\
& Hotel Management & 189 & 60 \\
Monthly Salary & Degree & 110 & 34.9 \\
& Others & 16 & 5.1 \\
& Rs 20000 - 30000 & 127 & 40.3 \\
& Rs 30000 - 40000 & 105 & 33.3 \\
Span of Experience & Rs 40000 - 50000 & 60 & 19 \\
& above Rs 50000 & 23 & 7.3 \\
& Oto2 years & 120 & 38.1 \\
& 2to5 years & 129 & 41 \\
& 5to10 years & 31 & 9.8 \\
& above 10 years & 35 & 11.1 \\
\hline
\end{tabular}

Source: Primary data

\section{Mediation Analysis Results}

Assessing the indirect effect of Talent Acquisition on Employee satisfaction through OCTAPACE Culture:

The mediating relationship between the variables of talent acquisition, OCTAPACE Culture, and employee satisfaction is tested through the mediation analysis. The analysis is presented in figure 2 . The results revealed that the path is evidenced with a beta coefficient 0.591 ; standard error is 0.054 and the path is found to be significant with p-value 0.000 . The path $b$ analysis revealed that the beta coefficient is 0.259 ; standard error is 0.058 and the $p$-value is found to be 0.000 . The direct effect of the model revealed that the beta coefficient is found to be 0.644 ; the standard error of the path is 0.056 and the p-value is 0.000 . The total effect of the model revealed that the beta coefficient is found to be 0.798 ; the standard error is 0.056 and the p-value is 0.000 . The analysis disclosed that path-a; path-b and path c' is found to be a significant and direct effect $(0.644)$ is found to be less than the total effect $(0.798)$. With these results, we conclude that the model processed a partial mediation. Further, the size and significance of the indirect effect are revealed as the regression coefficient is 0.153 and its standard error was 0.044 . The Bootstrapping results are found to be the lower control limits is 0.0744 and the upper control limit to be 0.2492 . As there is no zero between these points, we can conclude that the indirect effect is not zero and conceptually rejecting the null hypothesis.

Assessing the indirect effect of talent engagement on employee satisfaction through OCTAPACE Culture:

The mediating relationship between the variables of talent acquisition, OCTAPACE Culture, and employee satisfaction is tested through the mediation analysis. The analysis is presented in figure 3 . The results revealed that the path is evidenced with a beta coefficient 0.485 ; standard error is 0.061 and the path is found to be significant with p-value 0.000 . The path $b$ analysis revealed that the beta coefficient is 0.390 ; standard error is 0.057 and the $p$-value is found to be 0.000 . The direct effect of the model revealed that the beta coefficient is found to be 0.504 ; the standard error of the path is 0.066 and the p-value is 0.000 . The total effect of the model revealed that the beta coefficient is found to be 0.693; the standard error is 0.065 and the p-value is 0.000 . The analysis disclosed that path-a; path-b and path c' is found to be a significant and direct effect (0.504) is found to be less than the total effect (0.693). With these results, we conclude that the model processed a partial mediation. Further, the size and significance of the indirect effect were revealed as the regression coefficient is 0.189 and its standard error was 0.042 . The Bootstrapping results are found to be the lower control limit is 0.1147 and the upper control limit to be 0.2832 . As there is no zero between these points, we can conclude that the indirect effect is not zero and conceptually rejecting the null hypothesis.

\section{Assessing the indirect effect of talent development on employee satisfaction through OCTAPACE Culture:}

The mediating relationship between the variables of talent acquisition, OCTAPACE Culture, and employee satisfaction is tested through the mediation analysis. The analysis is presented in figure 4 . The results revealed that the path is evidenced with a beta coefficient 0.555 ; standard error is 0.064 and the path is found to be significant with p-value 0.000 . The path $b$ analysis revealed that the beta coefficient is 0.462 ; standard error is 0.062 and the p-value is found to be 0.000 . The direct effect of the model revealed that the beta coefficient is found to be 0.305 ; the standard error of

Marrybeth, J. K., Brackz, J. S., Hadson, W. B., \& Zlong, M. S. (2019). Talent acquisition and talent engagement practices significant impact over employee satisfaction. International Research Journal of Management, IT and Social Sciences, 6(6), 244-252. https://doi.org/10.21744/irjmis.v6n6.807 
the path is 0.562 and the p-value is 0.000 . The total effect of the model revealed that the beta coefficient is found to be 0.562 ; the standard error is 0.075 and the p-value is 0.000 . The analysis disclosed that path-a; path-b and path c' is found to be a significant and direct effect (0.305) is found to be less than the total effect (0.562). With these results, we conclude that the model processed a partial mediation. Further, the size and significance of the indirect effect were revealed as the regression coefficient is 0.256 and its standard error was 0.052 . The Bootstrapping results are found to be the lower control limits is 0.1644 and the upper control limit to be 0.3661 . As there is no zero between these points, we can conclude that the indirect effect is not zero and conceptually rejecting the null hypothesis.

\section{Assessing the indirect effect of talent retention on employee satisfaction through OCTAPACE Culture:}

The mediating relationship between the variables of talent acquisition, OCTAPACE Culture, and employee satisfaction is tested through the Hayes (2016) mediation analysis. The results revealed that the path is evidenced with a beta coefficient 0.606; standard error is 0.063 and the path is found to be significant with p-value 0.000 . The path $\mathrm{b}$ analysis revealed that the beta coefficient is 0.473 ; standard error is 0.064 and the p-value is found to be 0.000 . The direct effect of the model revealed that the beta coefficient is found to be 0.474 standard error of the path is 0.065 and the p-value is 0.000 . The total effect of the model revealed that the beta coefficient is found to be 0.543 ; the standard error is 0.076 and the p-value is 0.000 . The analysis disclosed that path-a; path-b and path c' is found to be a significant and direct effect (0.474) is found to be less than the total effect (0.543). With these results, we conclude that the model processed a partial mediation. Further, the size and significance of the indirect effect were revealed as the regression coefficient is 0.287 and its standard error was 0.059 . The Bootstrapping results are found to be the lower control limits is 0.1851 and the upper control limit to be 0.4235 . As there is no zero between these points, we can conclude that the indirect effect is not zero and conceptually rejecting the null hypothesis.

All the concerned mediation analysis results are summarized in the following table 3 . The results disclosed that all the proposed models exhibited partial mediation.

Table 3

Summary of mediating analysis

\begin{tabular}{|c|c|c|c|c|c|c|c|}
\hline $\begin{array}{l}\text { Independent } \\
\text { Variable } \\
\text { (X) }\end{array}$ & $\begin{array}{l}\text { Mediator } \\
\text { (M) }\end{array}$ & $\begin{array}{c}\text { Dependent } \\
\text { Variable } \\
\text { (Y) }\end{array}$ & $\begin{array}{c}\text { Step 1 } \\
\text { X->M } \\
\mathrm{a}=\text { Coeff } \\
\text { of X } \\
\text { a ;SE(a ); } \\
\text { p; } \\
\text { Rsquare }\end{array}$ & $\begin{array}{c}\text { Step 2 } \\
\text { M-> Y } \\
b=\text { Coeff of } \\
M \\
\text { b; SE(b); p; } \\
\text { Rsquare }\end{array}$ & $\begin{array}{c}\text { Step 3 } \\
\text { Total } \\
\text { Effect } \\
\text { X->Y } \\
\text { c=Coeff of } \\
\text { X } \\
\text { c;SE(c); p; } \\
\text { Rsquare }\end{array}$ & $\begin{array}{c}\text { Step } 4 \\
\text { Direct Effect } \\
\text { X,M -> Y } \\
\text { Coeff of X } \\
\text { c', SE(c'); }^{\prime} \text {. }\end{array}$ & $\begin{array}{c}\text { Indirect } \\
\text { Effect } \\
\mathrm{p}\end{array}$ \\
\hline $\begin{array}{l}\text { Talent } \\
\text { Acquisition }\end{array}$ & $\begin{array}{l}\text { OCTAPAC } \\
\text { E Culture }\end{array}$ & $\begin{array}{l}\text { Employee } \\
\text { satisfaction }\end{array}$ & $\begin{array}{l}0.591, \\
0.054, \\
0.000, \\
28.9\end{array}$ & $\begin{array}{l}0.259, \\
0.058, \\
0.000, \\
25.4\end{array}$ & $\begin{array}{l}0.798 \\
0.056 \\
0.000 \\
40.5\end{array}$ & $\begin{array}{l}0.644, \\
0.065, \\
0.000, \\
44.2\end{array}$ & $\begin{array}{l}0.153, \\
0.044, \\
0.000\end{array}$ \\
\hline $\begin{array}{l}\text { Talent } \\
\text { Engagement }\end{array}$ & $\begin{array}{l}\text { OCTAPAC } \\
\text { E Culture }\end{array}$ & $\begin{array}{l}\text { Employee } \\
\text { satisfaction }\end{array}$ & $\begin{array}{l}0.485, \\
0.061, \\
0.000, \\
17.7\end{array}$ & $\begin{array}{l}0.390, \\
0.057, \\
0.000, \\
25.4\end{array}$ & $\begin{array}{l}0.693, \\
0.065, \\
0.000, \\
27.9\end{array}$ & $\begin{array}{l}0.504, \\
0.066, \\
0.000, \\
37.6\end{array}$ & $\begin{array}{l}0.189, \\
0.042, \\
0.000\end{array}$ \\
\hline $\begin{array}{l}\text { Talent } \\
\text { Development }\end{array}$ & $\begin{array}{l}\text { OCTAPAC } \\
\text { E Culture }\end{array}$ & $\begin{array}{l}\text { Employee } \\
\text { satisfaction }\end{array}$ & $\begin{array}{l}0.555, \\
0.064, \\
0.000, \\
20.4\end{array}$ & $\begin{array}{l}0.462, \\
0.062, \\
0.000,25.4\end{array}$ & $\begin{array}{l}0.562, \\
0.075, \\
0.000, \\
16.1\end{array}$ & $\begin{array}{l}0.305, \\
0.077, \\
0.000, \\
29.2\end{array}$ & $\begin{array}{l}0.256, \\
0.052, \\
0.000\end{array}$ \\
\hline $\begin{array}{l}\text { Talent } \\
\text { Retention }\end{array}$ & $\begin{array}{l}\text { OCTAPAC } \\
\text { E Culture }\end{array}$ & $\begin{array}{l}\text { Employee } \\
\text { satisfaction }\end{array}$ & $\begin{array}{l}0.606, \\
0.063, \\
0.000, \\
24.0\end{array}$ & $\begin{array}{l}0.473, \\
0.064, \\
0.000, \\
25.4\end{array}$ & $\begin{array}{l}0.543, \\
0.076, \\
0.000, \\
14.8\end{array}$ & $\begin{array}{l}0.256, \\
0.080, \\
0.000, \\
27.9\end{array}$ & $\begin{array}{l}0.287, \\
0.059 \\
0.000\end{array}$ \\
\hline
\end{tabular}


Implications of the Study:

Research findings of this study revealed the factors affecting the HRD Practices of management education in the Indian context. The study identified the variables such as institutional brand, recruitment, and selection, infrastructure, work environment and compensation as the important factors that affect the talent acquisition. The variables namely role clarity, goal, and process clarity and work-life balance of the employees influence talent engagement. Learning and professional development and performance appraisal system of the institution will significantly influence the talent development. Employee welfare and safety, career management and rewards and benefits are identified as the vital factors affecting the talent retention in the institutions offering management education. Further, this study disclosed that OCTAPACE Culture playing a crucial mediating role in enhancing employee satisfaction through the effective implementation of HRD Practices. This empirical study helps to understand the mediating role of OCTAPACE Culture over HRD Practices to determine employee satisfaction. This study has resulted in the number of implications which are useful for both the academia and industry in the Indian management education in the specific and higher education sector in general.

\section{Conclusion}

It is observed that talent acquisition and talent engagement practices have a significant impact on employee satisfaction in the deemed universities. It is also disclosed that talent development and talent retention practices are found to be insignificant. It clearly indicates that the deemed universities are keen on talent acquisition and talent engagement, but they are failed in implementing talent development as well as talent retention strategies. Further, this analysis unveiled that talent acquisition and talent development practices have a significant impact on employee satisfaction in business schools. It is also disclosed that the talent engagement and talent retention practices are found to be insignificant. It clearly indicates that business schools are keen on talent acquisition and talent development, but they are failed in implementing talent engagement as well as talent retention strategies.

The results of the study observed that talent acquisition, talent engagement, and talent development practices have a significant impact on employee satisfaction in the Three Star Hotels. It is also disclosed that talent retention practices are found to be insignificant. It clearly indicates that the Three Star Hotels are keen on talent acquisition, talent engagement and talent development, but they are failed in implementing the talent retention strategies. Another important observation which we can understand from the results of this research paper is, irrespective of the organization the employees did not show confidence in the talent retention practices. Hence, it is suggested to develop retention strategies to enhance employee satisfaction among the hotel employees.

\section{Conflict of interest statement}

The authors declared that they have no competing interests.

\section{Statement of authorship}

The authors have a responsibility for the conception and design of the study. The authors have approved the final article.

\section{Acknowledgments}

The authors would like to thank the editor of IRJMIS for their valuable time, support and advice in completing the current study. 


\section{References}

Bedarkar, M., \& Pandita, D. (2014). A study on the drivers of employee engagement impacting employee performance. Procedia-Social and Behavioral Sciences, $133, \quad 106-115$. https://doi.org/10.1016/j.sbspro.2014.04.174

Beechler, S., \& Woodward, I. C. (2009). The global "war for talent”. Journal of international management, 15(3), 273-285. https://doi.org/10.1016/j.intman.2009.01.002

Budhwar, P. S., \& Sparrow, P. R. (2002). An integrative framework for understanding cross-national human resource management practices. Human Resource Management Review, 12(3), 377-403. https://doi.org/10.1016/S10534822(02)00066-9

Cardon, M. S., \& Stevens, C. E. (2004). Managing human resources in small organizations: What do we know?. Human resource management review, 14(3), 295-323. https://doi.org/10.1016/j.hrmr.2004.06.001

Cooke, F. L., Saini, D. S., \& Wang, J. (2014). Talent management in China and India: A comparison of management perceptions and human resource practices. Journal of World Business, 49(2), 225-235. https://doi.org/10.1016/j.jwb.2013.11.006

de Araújo Burcharth, A. L., Knudsen, M. P., \& Søndergaard, H. A. (2014). Neither invented nor shared here: The impact and management of attitudes for the adoption of open innovation practices. Technovation, 34(3), 149-161. https://doi.org/10.1016/j.technovation.2013.11.007

Dries, N. (2013). The psychology of talent management: A review and research agenda. Human Resource Management Review, 23(4), 272-285. https://doi.org/10.1016/j.hrmr.2013.05.001

Epstein, M. J. (2005). The determinants and evaluation of merger success. Business Horizons, 48(1), 37-46. https://doi.org/10.1016/j.bushor.2004.10.001

Gallardo-Gallardo, E., Nijs, S., Dries, N., \& Gallo, P. (2015). Towards an understanding of talent management as a phenomenon-driven field using bibliometric and content analysis. Human Resource Management Review, 25(3), 264-279. https://doi.org/10.1016/j.hrmr.2015.04.003

Gelens, J., Dries, N., Hofmans, J., \& Pepermans, R. (2013). The role of perceived organizational justice in shaping the outcomes of talent management: A research agenda. Human Resource Management Review, 23(4), 341-353. https://doi.org/10.1016/j.hrmr.2013.05.005

Hall, D. T., \& Moss, J. E. (1998). The new protean career contract: Helping organizations and employees adapt. Organizational dynamics, 26(3), 22-37. https://doi.org/10.1016/S0090-2616(98)90012-2

Hartmann, E., Feisel, E., \& Schober, H. (2010). Talent management of western MNCs in China: Balancing global integration and local responsiveness. Journal of world business, 45(2), 169-178. https://doi.org/10.1016/j.jwb.2009.09.013

Hayes, A. F. (2016). The PROCESS macro for SPSS and SAS. Retrieved from.

Hiltrop, J. M. (1996). The impact of human resource management on organisational performance: Theory and research. European Management Journal, 14(6), 628-637. https://doi.org/10.1016/S0263-2373(96)00059-X

Meyers, M. C., \& Van Woerkom, M. (2014). The influence of underlying philosophies on talent management: Theory, implications for practice, and research agenda. Journal of World Business, 49(2), 192-203. https://doi.org/10.1016/j.jwb.2013.11.003

Schiemann, W. A. (2014). From talent management to talent optimization. Journal of World Business, 49(2), $281-288$. https://doi.org/10.1016/j.jwb.2013.11.012

Snipes, R. L., Oswald, S. L., LaTour, M., \& Armenakis, A. A. (2005). The effects of specific job satisfaction facets on customer perceptions of service quality: an employee-level analysis. Journal of business research, 58(10), 13301339. https://doi.org/10.1016/j.jbusres.2004.03.007

Tarique, I., \& Schuler, R. S. (2010). Global talent management: Literature review, integrative framework, and suggestions for further research. Journal of world business, 45(2), 122-133. https://doi.org/10.1016/j.jwb.2009.09.019

Thunnissen, M., Boselie, P., \& Fruytier, B. (2013). Talent management and the relevance of context: Towards a pluralistic approach. Human Resource Management Review, 23(4), 326-336. https://doi.org/10.1016/j.hrmr.2013.05.004

Vaiman, V., Haslberger, A., \& Vance, C. M. (2015). Recognizing the important role of self-initiated expatriates in effective global talent management. Human Resource Management Review, 25(3), $280-286$. https://doi.org/10.1016/j.hrmr.2015.04.004

Yang, J. T. (2007). Knowledge sharing: Investigating appropriate leadership roles and collaborative culture. Tourism management, 28(2), 530-543. https://doi.org/10.1016/j.tourman.2006.08.006 